\title{
4. APATITE FISSION TRACK ANALYSIS OF SITES 959 AND 960 ON THE TRANSFORM CONTINENTAL MARGIN OF GHANA, WEST AFRICA ${ }^{1}$
}

\author{
Peter D. Clift, ${ }^{2}$ Andrew Carter, ${ }^{3}$ and Anthony J. Hurford ${ }^{3}$
}

\begin{abstract}
Four samples of sandstone from deformed Aptian-Albian sediments and their less deformed Turonian cover at Sites 959 and 960 on the Côte d'Ivoire-Ghana Marginal Ridge yielded sufficient apatite for fission track analysis. Reduced mean track length values of $12.42 \pm 0.16 \mu \mathrm{m}$ to $13.67 \pm 0.11 \mu \mathrm{m}$ indicate that measured central ages, which range from $88 \pm 4 \mathrm{Ma}$ to $113 \pm$ $4 \mathrm{Ma}$, have undergone partial resetting and are therefore apparent ages. Stochastic modeling of the fission track age and length parameters indicate that the samples have a strong predepositional signal, slightly modified by minor levels of prolonged postdepositional annealing (maximum temperatures $<80^{\circ} \mathrm{C}$ ). The preserved provenance-related signal records cooling through the apatite partial annealing zone $\left(60^{\circ}-110^{\circ} \mathrm{C}\right)$ during the Late Jurassic and Early Cretaceous, prior to $100 \mathrm{Ma}$ (Albian). The absence of substantial postdepositional annealing suggests that the Marginal Ridge was not significantly heated by the passage of an oceanic spreading center along the transform margin during the Turonian $(\approx 90 \mathrm{Ma})$. Instead the fission track data record cooling in response to denudation of the sediment source terrain initiated during the intracontinental wrench phase of tectonism. The $110^{\circ} \mathrm{C}$ of cooling corresponds to approximately $4 \mathrm{~km}$ of denudation, assuming normal geothermal gradients, a figure that is comparable to measured erosion along the flanks of the northern San Andreas fault or inferred from the Dead Sea.
\end{abstract}

\section{INTRODUCTION}

The Côte d'Ivoire-Ghana Marginal Ridge of West Africa is a classic example of a continental margin formed by breakup along a transform plate boundary (Fig. 1). The southern edge of the rifted margin is marked by the presence of a prominent ridge of acoustic basement (e.g., Mascle and Blarez, 1987; Mascle et al., 1989), which was sampled by submersible (Mascle et al., 1994), and by drilling during Ocean Drilling Program (ODP) Leg 159 (Mascle, Lohmann, Clift, et al., 1996). The acoustic basement was identified as tectonized clastic sediments of Aptian-Albian age, which were probably deposited within an intracontinental pull-apart basin system before undergoing structural inversion (Shipboard Scientific Party, 1996a). The Marginal Ridge itself is unconformably overlain by mid-Cretaceous (Turonian) shallow-water carbonates and quartzose clastic sediments, in turn succeeded by an Upper Cretaceous deep-water assemblage of shales, porcellanites, and carbonates (Shipboard Scientific Party, 1996b, 1996c). The origin of the Marginal Ridge has been a matter of some debate, although it is generally believed to reflect a combination of uplift during the intracontinental wrench phase of deformation, accentuated by thermally driven uplift during the passage of a spreading axis along the transform margin during the period of active ocean/continent transform motion (e.g., Basile et al., 1993). Geophysical modeling of transform margins assuming local isostatic compensation (e.g., Todd and Keen, 1989) suggests that the conduction of heat from the young oceanic plate into the thermally older rifted continental plate across the transform boundary can generate in excess of $2.5 \mathrm{~km}$ of uplift close to the ocean/continent boundary, depending on the duration of the active ocean/continent transform phase. Such uplift is driven by the transfer of significant heat, which would be expected to reach a maximum at the point of ridge/transform intersection and then show a progressive cooling. Such heating and uplift are concentrated close to the transform boundary and de-

'Mascle, J., Lohmann, G.P., and Moullade, M. (Eds.), 1998. Proc. ODP, Sci. Results, 159: College Station, TX (Ocean Drilling Program).

${ }^{2}$ Department of Geology, Woods Hole Oceanographic Institution, Woods Hole, MA 02543, U.S.A.pclift@whoi.edu

${ }^{3}$ Department of Geological Sciences, University College, London, United Kingdom. crease rapidly away from this contact, falling to $<20 \%$ of the maximum within $30 \mathrm{~km}$ of the ocean/continent boundary at the time of ridge/transform intersection. Temperature anomalies were predicted to be several hundred degrees above normal at the same time, even at shallow levels of the crust. The precise magnitude and distribution of the temperature anomalies depends on the speed of spreading and the size of the transform offset (Todd and Keen, 1989).

The time of ridge/transform intersection is poorly constrained. Regional plate tectonic reconstructions (e.g., Klitgord and Schouten 1986; Wilson and Guiraud, 1992) suggest that this occurred during the Turonian. The identification of an unconformity between Albian and Turonian sediments at Sites 959 and 960 (Shipboard Scientific Party, 1996b, 1996c) is also compatible with such a reconstruction. Dating the intersection using magnetic methods is impossible as the adjacent oceanic plate has no identifiable lineations, owing to its formation during the Cretaceous magnetic quiet period. Direct dating of the oceanic crust in this region is prevented by the large $(\approx 2.3 \mathrm{~km})$

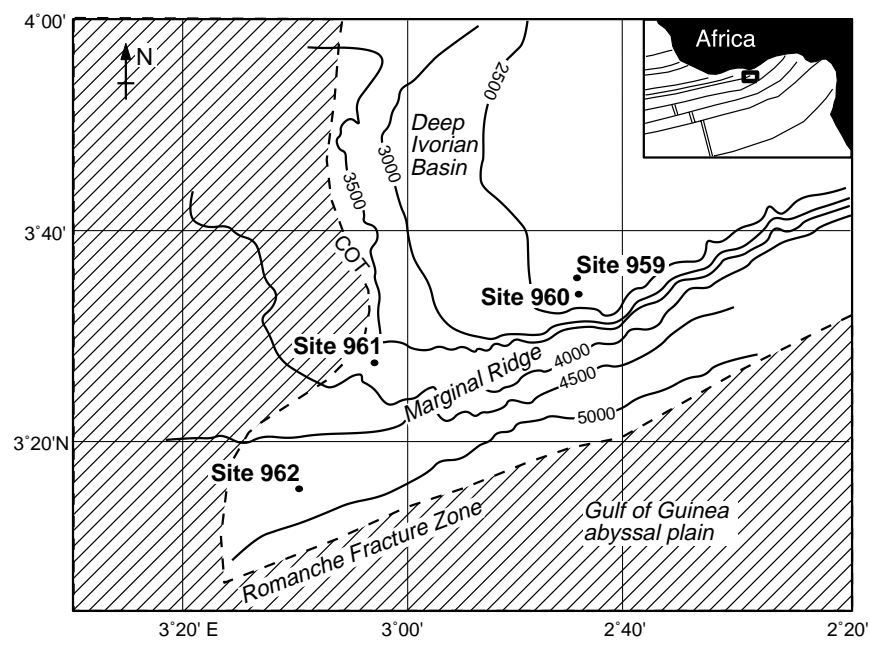

Figure 1. Bathymetric map of the Côte d'Ivoire-Ghana Transform Margin and the locations of Sites 959 and 960, from which the sediments analyzed in this study were extracted. 
thickness of sediment overlying oceanic basement in the Gulf of Guinea. An alternative approach is to examine the thermal consequences of ridge/transform intersection. With increased heat flow predicted at the point of ridge/transform intersection, it is possible that low-temperature dating systems might be reset at this time. Bouillin et al. (1994) attempted to date ridge/transform intersection using apatite fission track analysis, a technique that allows determining the time and rate of cooling of a body of rock through a temperature range of $60^{\circ}-110^{\circ} \mathrm{C}$ (equivalent to the upper $4-5 \mathrm{~km}$ of crust). Preliminary fission track cooling ages for samples of the AptianAlbian tectonized units recovered by submersible dives on the southern flank of the Marginal Ridge ranged from the Late Cretaceous to Eocene, although re-examination of the same samples gave only older ages, which ranged from 68 to $92 \mathrm{Ma}$ (Bouillin et al., in press). These samples were interpreted, on the basis of limited track length data (insufficient for the purposes of stochastic modeling), as reset ages that cooled rapidly from temperatures $>120^{\circ} \mathrm{C}$. The most probable cause of resetting and rapid cooling, ridge/transform intersection, would therefore have taken place at about $90 \mathrm{Ma}$, which is consistent with large-scale plate reconstructions (e.g., Klitgord and Schouten, 1986; Rabinowitz and LaBrecque, 1979).

In this study apatite fission track analysis is used to constrain the cooling history of the tectonized sediments and overlying cover at Sites 959 and 960 on the crest of the Marginal Ridge within $5 \mathrm{~km}$ of the transform plate boundary. The testing of geophysical models on the thermal evolution of transform margins (e.g., Todd and Keen, 1989 ) is hindered by the small amount of research in these regions and a lack of appropriate sampling. Sites 959 and 960 provide unique opportunities to collect new data in a critical area. Apatite fission track analysis can provide useful constraints on transform margin development by demonstrating the relative timing of rapid cooling of the sandstone apatites in relation to the time of sedimentation and probable ridge/transform intersection. Apatite fission track analysis has become an integral part of regional tectonic studies providing unique low-temperature data, which can quantify denudation and provide estimates of missing sections and eroded sediment volumes (e.g., Andriessen, 1995, and references therein). The technique has been applied to rifted passive margins in Norway (e.g., Rohrman et al., 1995), Newfoundland (Hendriks et al., 1993), and the Gulf of Suez (Omar et al., 1989), and can also be used to constrain the thermal history of sedimentary basins (Green et al., 1989; Naeser et al., 1989) including the timing and magnitude of maximum paleotemperatures.

\section{SAMPLE SELECTION AND EXPERIMENTAL PROCEDURES}

Eleven samples were selected for analysis from suitable clastic sequences at ODP Sites 959 and 960. Sediments at Sites 961 and 962 were considered to be too fine grained for apatite fission track analysis, as ideally, grain size should be $>60 \mu \mathrm{m}$. Because the maximum ODP sample volume is only $50 \mathrm{~cm}^{3}$, samples were usually amalgamated to produce a single sample large enough to yield a practical number of apatite grains. Samples were amalgamated from a number of cores, but in each case care was taken not to mix sediment of significantly different depositional ages. The samples are detailed in Table 1 , and where ODP samples were amalgamated the original sample identifiers are provided. Only one sample from Site 960 spans as many as three cores, 159-960A-59R through 61R, all within AptianAlbian tectonized sandstones. Apatites were extracted using standard magnetic and heavy-liquid separation techniques; however, despite careful sample selection, apatite yields were generally low, and only four yielded adequate numbers of grains for analysis. Part of the reason for this failure may lie with the small volume of the composite samples (weighing between 200 and 300 g), which are low by normal fission track standards.

Table 1 shows the details of each sample analyzed, including its inferred stratigraphic age of deposition. Background information on each site and the depths below seafloor of the cores are provided in the ODP Leg 159 Initial Reports volume (Mascle, Lohmann, Clift, et al., 1996). The age was taken from biostratigraphic information collected during Leg 159 (Mascle, Lohmann, Clift, et al., 1996), and a numerical age was allotted from the Gradstein et al. (1995) time scale. Present-day temperatures of sediments shown are calculated from the in situ temperature measurements taken at Sites 959 and 960 using the Lamont-Doherty Temperature Logging Tool (TLT; Shipboard Scientific Party, 1996b, 1996c). The modern temperatures are all less than $30^{\circ} \mathrm{C}$, well below the point of significant apatite fission track annealing, and therefore, earlier thermal history information will be preserved.

Fission track analysis followed procedures given in Storey et al. (1996). Samples were irradiated in the thermal facility of the Ris $\varnothing$ Reactor, National Research Centre, Rosklide, Denmark, (cadmium ratio for $\mathrm{Au}>400$ ), using Corning glass $\mathrm{CN}-5$ as neutron dosimeter. Counting and track length measurements used a microscope total magnification of $1250 \times$ with a $100 \times$ dry objective. Central ages were calculated using the IUGS-recommended zeta calibration approach (Hurford and Green, 1983; Hurford, 1990).

\section{FISSION TRACK RESULTS AND INTERPRETATION}

The results of fission track analysis are shown in Table 1 and displayed graphically in Figure 2. For each sample the range of component grain ages are displayed on radial plots (Galbraith, 1990) together with a track length distribution. Radial plots are used to permit comparison of crystals with differing ages and precision's. The position on the $\mathrm{x}$ scale records the relative precision of individual age estimates with each point having the same standardized error in the $y$ direction. The age of a given point on the plot is given by projecting a line from the origin on the left-hand side, through the point on to the circular scale on the right-hand side. Such plots are needed to examine the distribution of grain ages when a sample is seen to contain a heterogeneous population, indicated by the $\mathrm{Chi}^{2}$ test. A spread in grain ages may be due to provenance, or partial resettling enhanced by compositional effects. In Table 1 it is evident that only one sample (Cores 159-959D-73R and 74R) has a statistically meaningful spread in grain ages. The radial plot and age histogram (Fig. 2) for this sample show the spread is lacking in structure and has a minimal divergence beyond the central age. Hence, the central ages listed in Table 1 are a true reflection of the constituent grain ages, and there is no evidence for variation caused by apatite provenance and/or chemistry.

The next step in the interpretative process is to compare apatite central ages with the sediment depositional age to make a qualitative assessment as to the likelihood of postdepositional annealing (younger central ages signify annealing). Core sample 159-959D$71 \mathrm{R}$ has an apatite central age of $105 \pm 5 \mathrm{Ma}$, which overlaps the Cenomanian-late Albian depositional age of 95-101 Ma, while the slightly deeper $(\sim 20 \mathrm{~m})$ core Sample $159-959 \mathrm{D}-73 \mathrm{R}$ and $74 \mathrm{R}$ has a central age of $88 \pm 4 \mathrm{Ma}$, which is marginally younger than the late Albian depositional age of $>97 \mathrm{Ma}$. These data suggest that some minor postdepositional annealing may have occurred. In contrast, the two samples from Site 960 record central ages of $113 \pm 3 \mathrm{Ma}$ and 108 $\pm 4 \mathrm{Ma}$ that are older or within error of their Turonian (88-89 Ma) and Aptian-early Albian (110-120 Ma) depositional ages. Such close proximity of central ages to depositional age prevent robust identification of postdepositional annealing. Fission track length data are more sensitive indicators of annealing. 
Table 1. Fission track apatite analytical data from the Côte d'Ivoire-Ghana Transform Margin.

\begin{tabular}{|c|c|c|c|c|c|c|c|c|c|c|c|c|c|c|c|c|c|}
\hline \multirow[b]{2}{*}{ Core sample } & \multirow[b]{2}{*}{$\begin{array}{c}\text { Weight } \\
(\mathrm{g})\end{array}$} & \multirow{2}{*}{$\begin{array}{c}\text { Present borehole } \\
\text { temperature } \\
\left({ }^{\circ} \mathrm{C}\right)\end{array}$} & \multirow{2}{*}{$\begin{array}{l}\text { Borehole } \\
\text { depth } \\
\text { (m) }\end{array}$} & \multirow[b]{2}{*}{ Stratigraphic age (Ma) } & \multirow[b]{2}{*}{$\begin{array}{c}\text { Crystals } \\
\text { (no.) }\end{array}$} & \multicolumn{2}{|c|}{ Dosimeter } & \multicolumn{2}{|c|}{ Spontaneous } & \multicolumn{2}{|c|}{ Induced } & \multicolumn{2}{|c|}{ Age dispersion } & \multirow{2}{*}{$\begin{array}{c}\text { Central age } \\
\text { (Ma) } \\
\pm 1 \sigma\end{array}$} & \multirow{2}{*}{$\begin{array}{l}\text { Mean } \\
\text { track length } \\
(\mu \mathrm{m})\end{array}$} & \multirow[b]{2}{*}{$\begin{array}{l}\text { Standard } \\
\text { deviation }\end{array}$} & \multirow[b]{2}{*}{ Trac } \\
\hline & & & & & & $\rho d$ & $\mathrm{Nd}$ & $\rho s$ & Ns & $\mathrm{i}$ & $\mathrm{Ni}$ & $\left(\chi^{2}\right)$ & $(\%)$ & & & & \\
\hline 159-959D- & & & & & & & & & & & & & & & & & \\
\hline $\begin{array}{l}71 R \\
73 R \text { and } 74 R\end{array}$ & $\begin{array}{l}259 \\
217\end{array}$ & $\begin{array}{l}<30 \\
<30\end{array}$ & $\begin{array}{c}1081 \\
1100-1120\end{array}$ & $\begin{array}{l}\text { Cenomanian to late Albian (95-101 Ma) } \\
\text { late Albian or older (>97 Ma) }\end{array}$ & $\begin{array}{l}26 \\
45\end{array}$ & $\begin{array}{l}1.295 \\
1.295\end{array}$ & $\begin{array}{l}7179 \\
7179\end{array}$ & $\begin{array}{l}1.326 \\
1.029\end{array}$ & $\begin{array}{r}836 \\
1429\end{array}$ & $\begin{array}{l}2.746 \\
2.543\end{array}$ & $\begin{array}{l}1732 \\
3531\end{array}$ & $\begin{array}{c}37 \\
0.0\end{array}$ & $\begin{array}{r}0.8 \\
19.6\end{array}$ & $\begin{array}{l}105 \pm 5 \\
88 \pm 4\end{array}$ & $\begin{array}{l}12.42 \pm 0.16 \\
12.86 \pm 0.13\end{array}$ & $\begin{array}{l}1.30 \\
1.30\end{array}$ & $\begin{array}{r}69 \\
101\end{array}$ \\
\hline $159-960 \mathrm{~A}-$ & & & & & & & & & & & & & & & & & \\
\hline $37 \mathrm{R}$ and $38 \mathrm{R}$ & 319 & $<30$ & $328-347$ & Turonian (88-89 Ma) & 45 & 1.295 & 7179 & 1.182 & 1933 & 2.277 & 3724 & 35 & 2.5 & $113 \pm 3$ & $13.67 \pm 0.11$ & 1.14 & 106 \\
\hline $59 \mathrm{R}, 60 \mathrm{R}$, and $61 \mathrm{R}$ & 292 & $<30$ & $437-451$ & Aptian-early Albian (120-110 Ma) & 45 & 1.295 & 7179 & 1.008 & 1283 & 2.030 & 2583 & 62 & 3.1 & $108 \pm 4$ & $13.34 \pm 0.17$ & 1.55 & 83 \\
\hline
\end{tabular}

Notes: Track densities are $\left(\times 10^{6}\right.$ tracks $\left./ \mathrm{cm}^{2}\right)$ numbers of tracks counted. Analyses by external detector method using 0.5 for the $4 \pi / 2 \pi$ geometry correction factor. Ages calculated using dosimeter glass $\mathrm{CN}-5$ (apatite); analyst Carter; zeta CN-5 = $339 \pm 5$ calibrated by multiple analyses of IUGS apatite and zircon age standards (see Hurford, 1990). Central age is a modal age, weighted for different precisions of individual crystals (see Galbraith, 1990). 

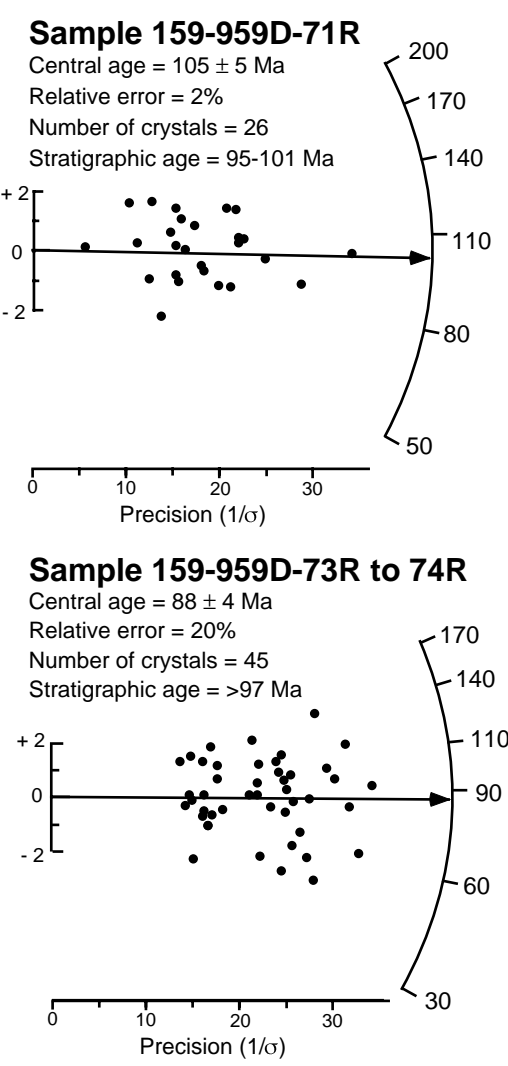

\section{Sample 159-960A-37R to 38R}

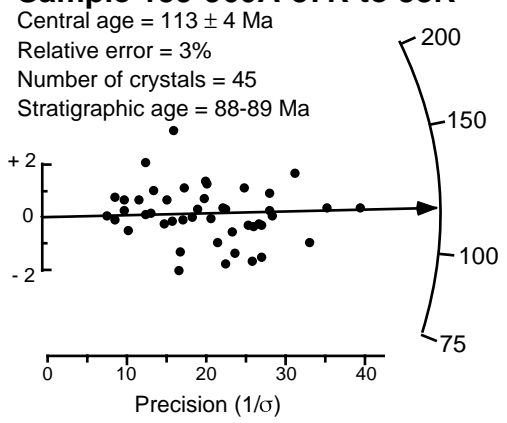

Sample 960A-59R, 60R, and 61R

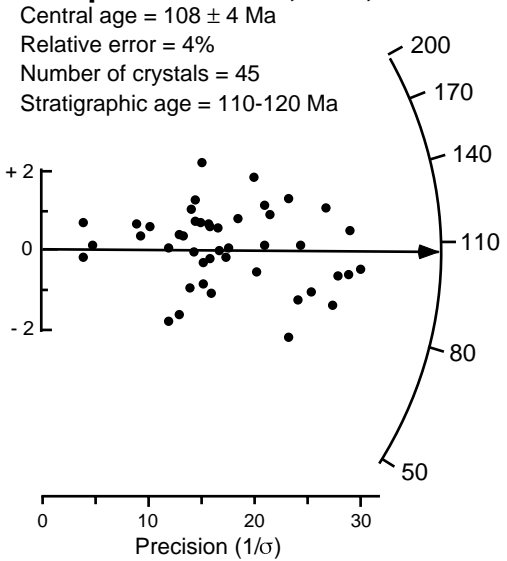

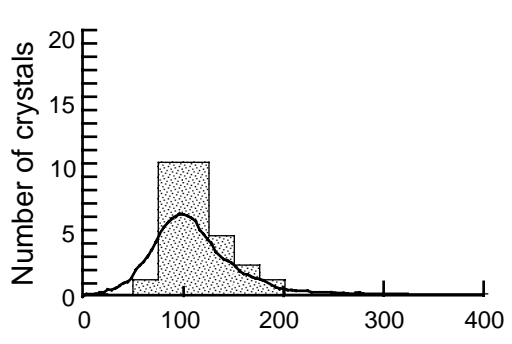

Fission track age (Ma)
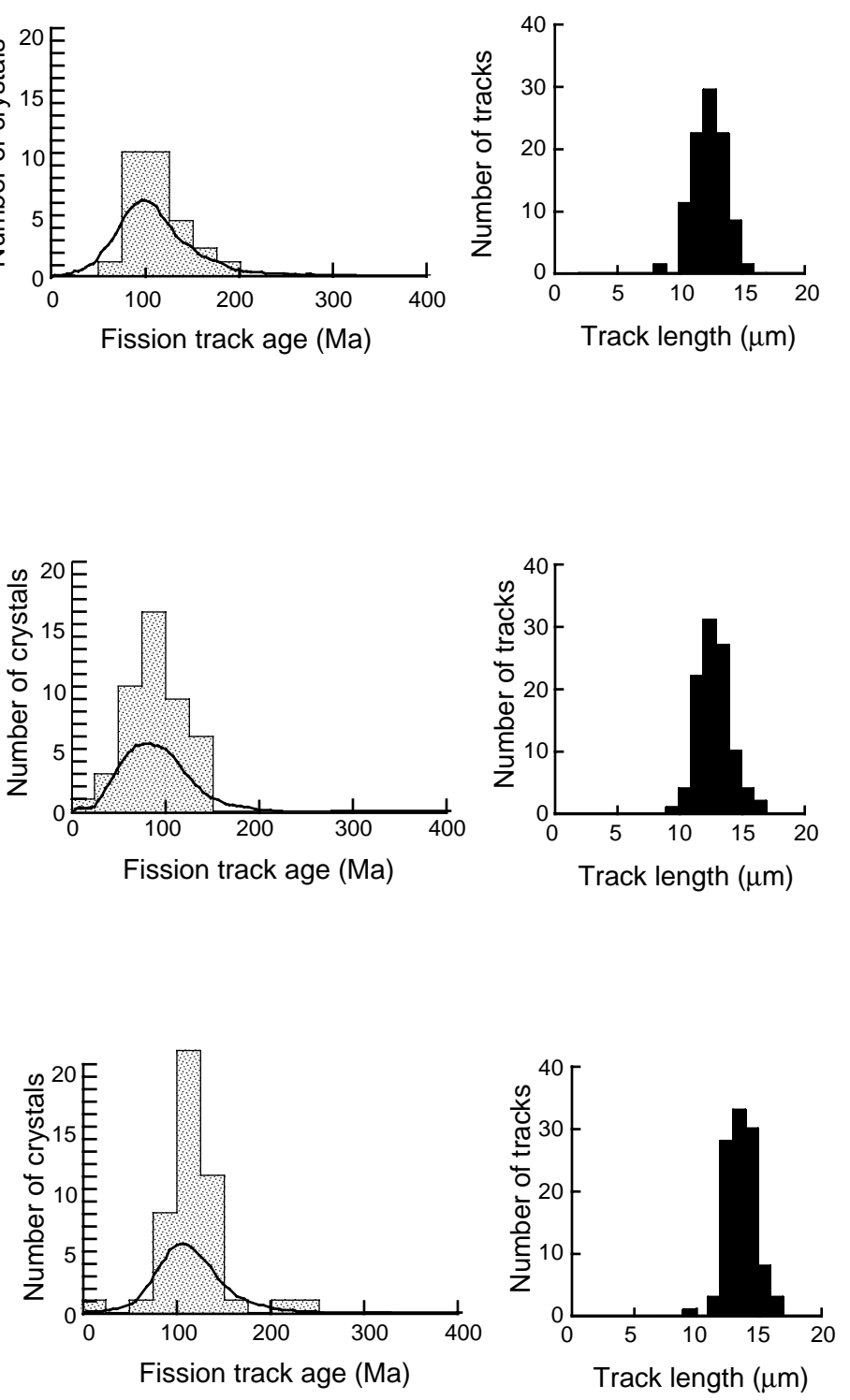

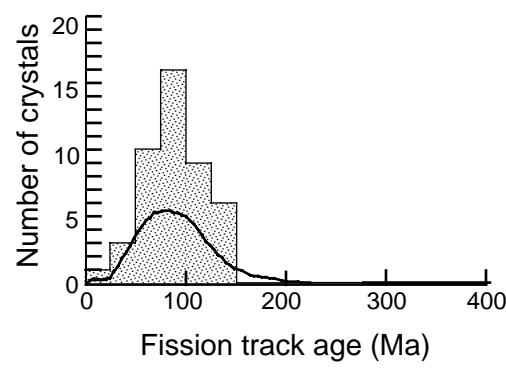

Track length $(\mu \mathrm{m})$
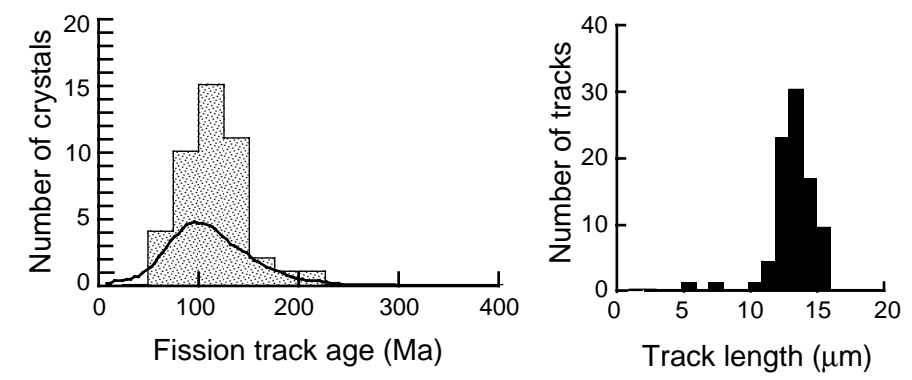

Figure 2. Fission-track grain age and track length data for the samples in Table 1 displayed as radial plots, age histograms, and track length distributions. 
Adequate numbers (50-100) of confined tracks were measured and in each sample define a unimodal form, which is generally indicative of a simple cooling history (Fig. 2). Mean track length values for the four samples range between $12.42 \pm 0.16 \mu \mathrm{m}$ and $13.67 \pm 0.11$ $\mu \mathrm{m}$. These lengths are below values normally attributed to rapidly cooled samples (unannealed apatites have mean lengths $>14 \mu \mathrm{m}$ ). Consequently the measured central ages are "apparent ages" and do not directly measure the time of cooling through the partial annealing zone. Since present-day downhole temperatures $\left(\leq 30^{\circ} \mathrm{C}\right)$ are not sufficient to reduce the mean lengths to their present values some postdepositional annealing must have occurred (i.e., temperatures were once above $60^{\circ} \mathrm{C}$ [the base of apatite partial annealing zone]). In order to decipher further the relationship between apparent central ages, measured track lengths, and probable thermal history, the fission track parameters need to undergo a form of stochastic modeling.

\section{THERMAL HISTORY MODELING AND TECTONIC IMPLICATIONS}

Modeling of fission track length and age data using the approach adopted in Gallagher (1995) allows a "best" cooling history for each sample to be identified. Confined track length distributions are invaluable thermal history indicators because track production is continuous throughout a sample's history, and, therefore, individual tracks record different parts of the thermal history. Central to understanding the relationship of measured fission track age and track length distribution is a modeling procedure that aims to produce a range of cooling history paths compatible with the fission track age and length data. In this study we used the method of Gallagher (1995), which is based on a form of stochastic simulation, of which an important aspect is deriving the thermal history with the maximum likelihood. A series of time-temperature points selected from specified time-temperature bounds are generated. From such points a thermal history is constructed and fission-track parameters (i.e., age and track length data) are predicted and compared with the measured data. Several thousand runs are produced for each sample, from which the best fitting paths are extracted to identify which aspects of the sample's thermal history are well resolved. Figure 3 shows the results of modeling the fission track data. For each sample the best fitting time-temperature path is shown along with the $95 \%$ uncertainty region for each time-temperature point that forms the path. This enables identification of which parts of a thermal history are better constrained, as well as defining limits on maximum partial annealing temperatures. From modeled results it is possible to identify several features common to all samples. Each sample requires a component of predepositional cooling during the Late Jurassic or Early Cretaceous. All samples experienced significant residence in the cooler part of the apatite partial annealing zone during the Tertiary. Maximum temperatures were between $60^{\circ}-80^{\circ} \mathrm{C}$, and were followed by recent cooling, although this is poorly resolved by the data. The low annealing temperatures were not sufficient to significantly overprint the component of inherited, predepositional tracks so that the measured central ages still either overlap or are older than the depositional age.

The fission track data suggest that apatites from the drilling samples were not significantly thermally reset by a passing ridge crest. The samples are characterized by minor postdepositional annealing of an earlier (Late Jurassic to Early Cretaceous) provenance-related track population. The apatite thermal history reflects cooling of the source terrain from which the apatites were eroded. As there is no appropriate source immediately north or east of the ridge, it is presumed that the sediment was derived from the relatively unrifted basement south of the transform zone (i.e., northeastern Brazil). This cooling predates the end of sedimentation of the tectonized sequences (uppermost Albian at Site 962; 98.9 Ma; Mascle, Lohmann, Clift, et al.,
1996). As the deformed nature of the sediments indicates that the margin must have been active up to this time, it is not possible for ridge/transform intersection to have occurred before the Cenomanian and probably before the Turonian (i.e., before 93.5 Ma), assuming that the deformation was principally a feature of intra-continental wrenching rather than active ocean/continent transform deformation. Because there is a strongly preserved predepositional signal in the fission track data any thermal effect of ridge/transform intersection can only be minor. The low level postdepositional annealing identified by the modeling may be due to minor, possibly burial-related annealing, although this is difficult to reconcile with the preserved stratigraphy and standard geothermal gradients. A geothermal gradient of $\sim 60^{\circ} \mathrm{C} /$ $\mathrm{km}$ would be required during much of the Tertiary, compared to a normal passive margin value of $30^{\circ} \mathrm{C} / \mathrm{km}$. A significantly higher geothermal gradient in the past may be linked to elevated heat flow associated with ridge/transform intersection. Unfortunately, the results are inconclusive, additional samples from greater depths $(+500-1000$ mbsf) would provide a clearer signal as the expected level of apatite track annealing would be much higher.

It is noteworthy that core Sample 159-960A-37R and 38R shows a similar cooling history to the other samples. Since this sediment was deposited above the unconformity in Hole 960A, the age of sedimentation is approximately synchronous with or just postdates the assumed time of ridge/transform intersection. That this sample shows the same average thermal history as the underlying deformed sediments indicates that the overlying shallow-water clastics are derived from erosion and reworking of the older deformed sediments and do not represent influx from a new source terrain. Such a pattern would be expected if ridge/transform intersection occurred at about $90 \mathrm{Ma}$ as this would remove the major sediment source terrain from south of Site 960, whereas the area north of there (i.e., the Deep Ivorian Basin) was already subsiding as a result of the earlier extensional phase. Consequently, reworking on the Marginal Ridge crest would be the only source of clastic material.

\section{Independent Temperature Estimates}

Temperature estimates based on clay mineralogy from the tectonized sediments at Site 959 indicate a peak temperature of $120^{\circ}$ $175^{\circ} \mathrm{C}$ toward the base of the drilled section (Core 159-959D-78R) and elevated geothermal gradients (about $350^{\circ} \mathrm{C} / \mathrm{km}$ ) at the time of peak heat flow (Holmes, Chap. 7, this volume). Such high gradients are anomalous for continental areas, but gradients of $>200^{\circ} \mathrm{C} / \mathrm{km}$ have been recorded in pull-apart basins (e.g., Imperial Valley of California; Robert, 1988). However, clay assemblages from Core 159959D-66R predict postdepositional peak temperatures of $<90^{\circ} \mathrm{C}$, which Holmes (Chap. 7, this volume) interpreted to reflect the presence of an unconformity within the tectonized units. Erosion of part of the lower tectonized units must have occurred before renewed sedimentation and deformation of the upper tectonized units. The fission track samples all lie above the zone of elevated temperatures (i.e., within the upper tectonized sediments of Holmes, Chap. 7, this volume), and are thus compatible with the clay temperature data. The same is true at Site 960, where the high-temperature diagenetic clay assemblages all lie below the depth of the apatite fission track samples. In addition, Marcano et al. (Chap. 8, this volume) used oxygen isotope data from veins within the tectonized and cover sediments to predict an event in which high-temperature $\left(<60^{\circ} \mathrm{C}\right)$ veins were emplaced after the Turonian. Such temperatures are not sufficient to cause significant annealing of the apatite fission tracks.

\section{CONCLUSIONS}

Taken together, these data sets indicate the presence of a transform margin basin with high heat flow undergoing active sedimenta- 

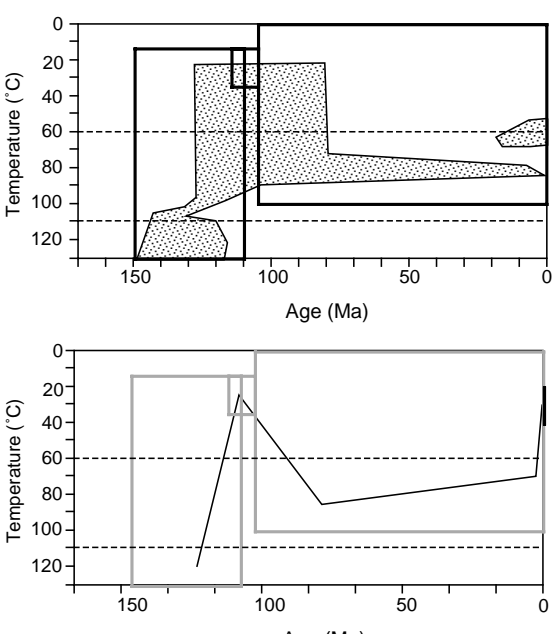

Age (Ma)

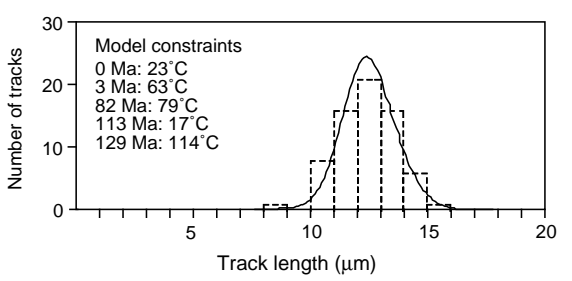

Observed age $=105.1 \mathrm{Ma}$

Predicted age $=105.0 \mathrm{Ma}$

Observed mean length $=12.42 \mu \mathrm{m}$

Predicted mean length $=12.32 \mu \mathrm{m}$

Observed standard deviation $=1.29$

Predicted standard deviation $=1.27$
Sample 959D-73R to $74 R$

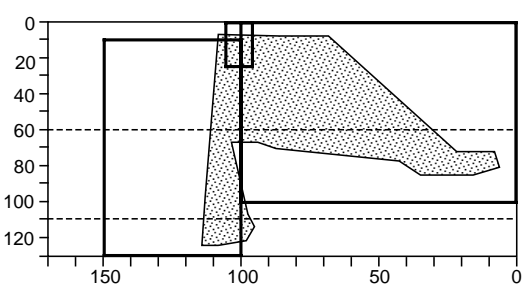

Age $(\mathrm{Ma})$

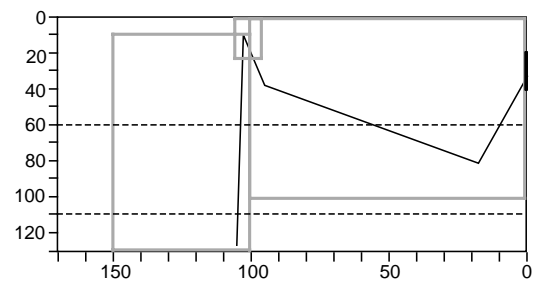

Age $(\mathrm{Ma})$

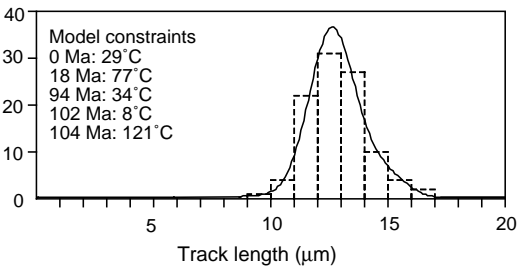

Observed age $=88.5 \mathrm{Ma}$

Predicted age $=88.4 \mathrm{Ma}$

Observed mean length $=12.86 \mu \mathrm{m}$

Predicted mean length $=12.77 \mu \mathrm{m}$

Observed standard deviation $=1.29$
Sample 159-960A-37R to 38R

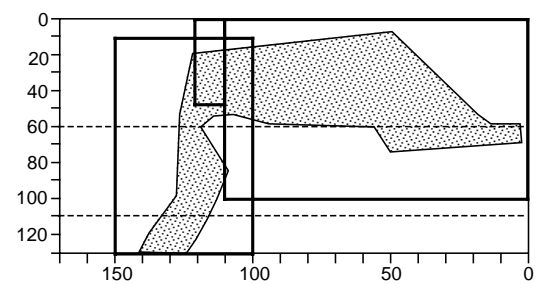

Age (Ma)

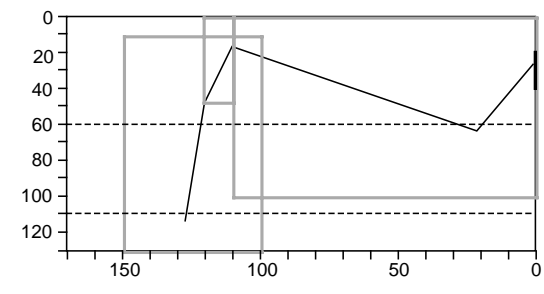

Age (Ma)

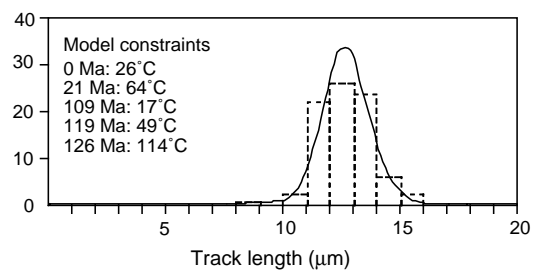

Observed age $=112.9 \mathrm{Ma}$

Predicted age $=113.0 \mathrm{Ma}$

Observed mean length $=13.68 \mu \mathrm{m}$

Predicted mean length $=13.57 \mu \mathrm{m}$

Observed standard deviation $=1.13$

Predicted standard deviation $=1.18$
Sample 159-960A-59R, 60R and 61R

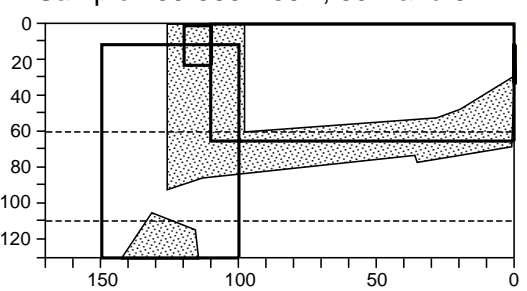

Age (Ma)

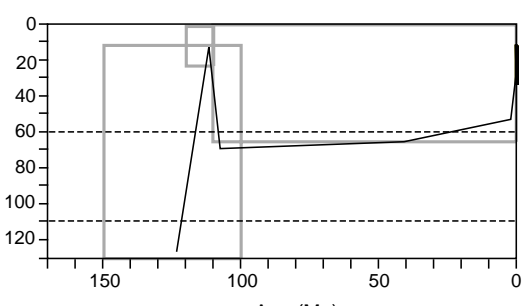

Age (Ma)

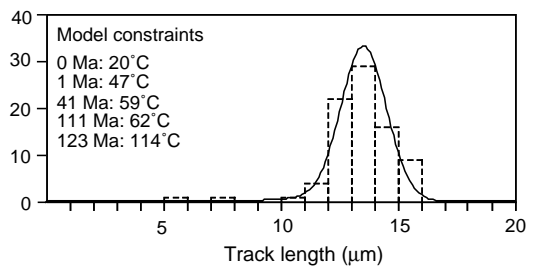

Observed age $=108.1 \mathrm{Ma}$

Predicted age $=108.1 \mathrm{Ma}$

Observed mean length $=13.34 \mu \mathrm{m}$

Predicted mean length $=13.35 \mu \mathrm{m}$

Observed standard deviation $=1.55$

Predicted standard deviation $=1.24$

Figure 3. Modeled thermal histories for samples from the Côte d'Ivoire-Ghana Transform Margin. For each sample the best-fit path (of predicted to measured data) is accompanied by the 95\% confidence region (shaded area) used to define temperature limits and show which parts of a thermal history are well constrained by the measured data. The boxes define the region within which random time-temperature points are plotted. 
tion and deformation during the Aptian-Albian. Syntransform deformation caused major uplift and erosion along the flanks of the basin with the eroded detritus forming fan deltas prograding into a lacustrine environment. Temporary inversion of the basin caused erosion at one point during this period, followed by renewed subsidence, sedimentation, and deformation. Finally, the basin was inverted into the Marginal Ridge between the late Albian and early Turonian, on the basis of the ages of the oldest posttectonic sediment and the youngest tectonized sediment. Ridge/transform intersection is presumed to have occurred during the early Turonian on the basis of regional plate tectonic reconstructions and the presence of an unconformity of this age affecting the section at Sites 959 and 960 . Fission track results indicate that intersection does not appear to have made a major thermal impact on the development of the Côte d'Ivoire-Ghana Marginal Ridge.

\section{ACKNOWLEDGMENTS}

PC acknowledges JOI/USSAC in supporting this work. We thank Kerry Gallagher and an anonymous reviewer for their help in improving this paper. This is WHOI contribution number 9412.

\section{REFERENCES}

Andriessen, P.A.M., 1995. Fission track analysis: principles, methodology and implications for tectono-thermal histories of sedimentary basins, orogenic belts and continental margins. Geol. Mijnbouw, 74:1-12.

Basile, C., Mascle, J., Popoff, M., Bouillin, J.P., and Mascle, G., 1993. The Côte d'Ivoire-Ghana transform margin: a marginal ridge structure deduced from seismic data. Tectonophysics, 222:1-19.

Bouillin, J.-P, Poupeau, G., Labrin, E., Basile, C., Sabil, N., Mascle, J., Mascle, G., Gillot, F., and Riou, L., in press. Fission track study of the marginal ridge of the Ivory Coast-Ghana transform margin. Geo-Mar. Lett.

Bouillin, J.P., Poupeau, G., Riou, L., Sabil, N., Basile, C., Mascle, J., Mascle, G., and the Equanaute Scientific Party, 1994. La marge transformante de Côte d'Ivoire-Ghana: premières donneés thermo-chronologiques (campagne Equanaute, 1992). C. R. Acad. Sci. Ser. 2, 318:1365-1370.

Galbraith, R.F., 1990. The radial plot: graphical assessment of spread in ages. Nucl. Tracks, 17:207-214.

Gallagher, K., 1995. Evolving temperatures histories from apatite fissiontrack data. Earth Planet. Sci. Lett., 136:421-435.

Gradstein, F.M., Agterberg, F.P., Ogg, J.G., Hardenbol, J., van Veen, P., Thierry, J., and Huang, Z., 1995. A Triassic, Jurassic and Cretaceous time scale. In Berggren, W.A., Kent, D.V., and Aubry, M.P. (Eds.), Geochronology, Time Scales and Global Stratigraphic Correlation. Spec. Publ.Soc. Econ. Paleontol. Mineral., 54:95-128.

Green, P.F., Duddy, I.R., Laslett, G.M., Hegarty, K.A., Gleadow, A.J.W., and Lovering, J.R., 1989. Thermal annealing of fission tracks in apatite: 4 quantitative modeling techniques and extension to geological timescales. Chem. Geol., 79:155-182.

Hendriks, M., Jameison, R.A., Willett, S.D., and Zentilli, M., 1993. Burial and exhumation of the Long Range Inlier and its surroundings, Newfoundland: results of an apatite fission-track study. Can. J. Earth Sci., 30:1594-1606.

Hurford, A.J, 1990. Standardization of fission track dating calibration: recommendation by the Fission Track Working Group of the I.U.G.S. Subcommission on Geochronology. Chem. Geol., 80:171-178.
Hurford, A.J., and Green, P.F., 1983. The zeta age calibration of fission track dating. Chem. Geol., 1:285-317.

Klitgord, K.D., and Schouten, H., 1986. Plate kinematics of the central Atlantic. In Vogt, P.R., and Tucholke, B.E. (Eds.), The Geology of North America (Vol. M): The Western North Atlantic Region. Geol. Soc. Am., 351-378.

Mascle, J., Auroux, C., and the Shipboard Scientific Team, 1989. Les marges continentales transformantes ouest-africaines (Guinée, Côte d'IvoireGhana) et la zone de fracture de la Romanche: Campagne Equamarge II (Février-Mars 1988). Campagn. Oceanogr. Fr. Publ. IFREMER

Mascle, J., and Blarez, E., 1987. Evidence for transform margin evolution from the Côte d'Ivoire-Ghana continental margin. Nature, 326:378-381.

Mascle, J., and Equanaute Scientific Party, 1994. Les marges continentales transformantes Ouest-Africaines-Côte d'Ivoire, Ghana, Guinée. IFREMER, Ser. Rep. Ocean, 5:1-119.

Mascle, J., Lohmann, G.P., Clift, P.D., et al., 1996. Proc. ODP, Init. Repts., 159: College Station, TX (Ocean Drilling Program).

Naeser, N.D., Naeser, C.W., and McCulloch, T.H., 1989. The application of fission-track dating to depositional and thermal history of rocks in sedimentary basins. In Naeser, N.D., and McCulloh, T.H. (Eds.), Thermal History Analysis in Sedimentary Basins: New York (Springer-Verlag), 181-195.

Omar, G.I., Steckler, M.S., Buck, W.R., and Kohn, B.P., 1989. Fission track analysis of basement apatites at the western margin of the Gulf of Suez rift, Egypt: evidence for synchroneity of uplift and subsidence. Earth Planet. Sci. Lett., 94:316-328.

Rabinowitz, P.D., and LaBrecque, J.L., 1979. The Mesozoic South Atlantic Ocean and evolution of its continental margins. J. Geophys. Res., 84:5973-6002.

Robert, P., 1988. Organic Metamorphism and Geothermal History: Dordrecht (D. Reidel).

Rohrman, M., van der Beek, P., Andriessen, P., and Cloetingh, S., 1995. Meso-Cenozoic morphotectonic evolution of southern Norway: Neogene domal uplift inferred from apatite fission track thermochronology. Tectonics, 14:704-718.

Shipboard Scientific Party, 1996a. Principal results. In Mascle, J., Lohmann, G.P., Clift, P.D., et al., Proc. ODP, Init. Repts., 159: College Station, TX (Ocean Drilling Program), 297-314.

, 1996b. Site 959. In Mascle, J., Lohmann, G.P., Clift, P.D., et al., Proc. ODP, Init. Repts., 159: College Station, TX (Ocean Drilling Program), 65-150.

1996c. Site 960. In Mascle, J., Lohmann, G.P., Clift, P.D., et al., Proc. ODP, Init. Repts., 159: College Station, TX (Ocean Drilling Program), 151-215.

Storey, B.C., Brown, R., Carter, A., Doubleday, P., Hurford, A.J., Macdonald D.I.M., and Nell, P.A.R., 1996. Fission-track evidence for the thermotectonic evolution of a Mesozoic-Cenozoic forearc region, Antarctica. $J$. Geol. Soc. London, 153:65-82.

Todd, B.J., and Keen, C.E., 1989. Temperature effects and their geological consequences at transform margins. Can. J. Earth Sci., 26:2591-2603.

Wilson, M., and Guiraud, R., 1992. Magmatism and rifting in Western and Central Africa, from Late Jurassic to Recent times. Tectonophysics, 213:203-225.

Date of initial receipt: 1 July 1996

Date of acceptance: 12 March 1997

Ms 159SR-004 